\title{
HIV Entry Inhibitor
}

National Cancer Institute

\section{Source}

National Cancer Institute. HIV Entry Inhibitor. NCI Thesaurus. Code C157400.

An agent that prevents the human immunodeficiency virus (HIV) from entering a cell. 